\title{
ANALISIS PARTISIPASI MASYARAKAT TERHADAP PELESTARIAN SITUS CAGAR BUDAYA SENDANG BEJI DESA KARANGPATIHAN, KABUPATEN PONOROGO
}

\author{
Sujud Tri Fajar Pamungkas ${ }^{1}$, Hadi Cahyono ${ }^{2}$, Prihma Sinta Utami ${ }^{3}$ \\ ${ }^{123}$ Prodi Pendidikan Pancasila dan Kewarganegaraan, Universitas Muhammadiyah \\ Ponorogo \\ Ponorogo, Indonesia
}

fajarpamungkas223@gmail.com ${ }^{1}, \underline{\text { hadicahyono0@gmail.com }}{ }^{2}, \underline{\text { prihma_utami@umpo.ac.id }}$

\begin{abstract}
Local culture is one of the keys in the realization of the national culture of the Indonesian nation. Strengthening the preservation of local culture that is starting to become extinct, such as cultural heritage, requires the participation of the local community to make it happen so that it is maintained. The Sendang Beji cultural heritage site in Ponorogo Regency has a historical story that must be preserved so that it can be known by future generations. The purpose of writing this article is to reveal the results of research on community participation in the preservation of the Sendang Beji cultural heritage site, Ponorogo Regency. The method used in this study is a qualitative descriptive method with data collection techniques, namely interviews, observation and documentation. The results of this study indicate that the form of community participation fulfills 5 components forms of participation, namely: a) participation of ideas; b) energy participation; c) property participation; d) participation skills and skills; and e) social participation
\end{abstract}

Keywords: community participation, cultural preservation, cultural heritage sites, spring beji, local cult

\section{PENDAHULUAN}

Ponorogo merupakan kota kecil yang berada di Jawa Timur yang memiliki berbagai situs budaya dan sejarah yang sangat banyak. Kesenaian dan budaya yang terkenal sampai mancanegara salah satunya ialah kesenian reog Ponorogo (Sulton et al., 2020). Oleh karena itu tak jarang Ponorogo dijuluki sebagai kota reog, dan masih banyak lagi kesenian, budaya Kabupaten Ponorogo yang belum terekspos. Selain kesenian, Ponorogo terdapat juga beberapa situs cagar budaya yang sampai saat ini masih lestari. Situssitus tersebut adalah bagian dari sejarah Kabupaten Ponorogo. Cagar budaya merupakan salah satu bukti konkrit sejarah yang memang harus dilestarikan. Dalam Undang-undang No 11 tahun 2010 tentang Cagar Budaya pasal 1 bahwa kita harus melestarikan keberadaan cagar budaya karena memiliki nilai penting bagi sejarah, ilmu pengetahuan, pendidikan, agama, dan kebudayaan melalui proses penetapan (Sularsih, 2012). Cagar budaya memang perlu dilestarikan dan dijaga mengingat nilai historis yang terkandung didalamnya. Kabupaten Ponorogo memiliki banyak sekali cagar budaya misalkan situs Makam Batoro Katong, situs Makam 
Astana Srandil, Makam Jayengrono, dan masih banyak lainnya yang semua itu berkaitan antara satu dengan lainnya.

Kebudayaan dapat digolongkan menjadi dua komponen utama, pertama kebudayaan secara materil dan kebudayaan secara non-materil. Kebudayaan materil mengacu pada semua bentuk ciptaan manusia secara konkret, dalam hal ini bisa berupa bendabenda temuan yang dihasilkan dari penggalian arkeologis, sedangkan kebudayaan yang non materil megacu pada bentuk abstrack yang diwariskan secara turun temurun kepada manusia, berupa dongeng, adat istiadat (Abdillah, 2020). Kebudayaan berupa materil ini merupakan situs-situs candi, situs purbakala, dan bangunan-bangunan lain, kebudayaan materil ini perlu di lestarikan dengan baik. Mengacu pada UU No 11 Tahun 2010 tentang Cagar Budaya, tempat-tempat cagar budaya ini digunakan sebagai bentuk pendidikan, dan ilmu pengetahuan.

Pelestarian menurut KBBI diartikan sebagai proses pengelolaan, perlindungan dari kemusnahan dan menjamin kebermanfaatannya secara bijaksana dan menjamin kesinambungan serta tetap memelihara dan meingkatkan nilai dari suatu tempat (Arinto, 2018). Pelestarian menjadi sebuah hal yang penting dalam situs cagar budaya. Dengan pelestarian sebuah situs cagar budaya, generasigenerasi berikutnya akan mengetahui bahwasannya suatu tempat memiliki sejarah dan nilai-nilai budaya didalamnya. Pelestarian sebuah kawasan cagar budaya merupakan segenap proses konservasi, interpretasi, dan manajemen terhadap suatu kawasan agar makna kultural yang terkandung didalamnya tetap terjaga (Amanda \& Suprihardjo, 2012).

Pelestarian warisan budaya bangsa adalah wujud sebagai ikhtiar dalam memupuk dan menanamkan rasa kebanggaan nasional dan juga wujud untuk turut dalam memperkokoh jatidiri bangsa. Jika kita melihat bahwasannya masyarakat Indonesia merupakan masyarakat dengan realitas multikultural, hal ini menunjukkan bahwa kebudayaankebudayaan lokal semakin beragam dan akan memperkaya jati diri bangsa Indonesia itu sendiri (Cahyono et al., 2020). Budaya lokal merupakan kunci dari terwujudnya budaya nasional yang perlu dipertahankan kelestariannya untuk generasi penerus selanjutnya, hal ini sebagai wujud penguatan cinta tanah air masyarakat. (Wulansari \& Utami, 2019). Langkah-langkah dalam pelestarian cagar budaya, sangat besar dalam membentuk kepentingan pembinaan warga negara serta pengembangan sejarah dalam suatau negara, ilmu pengetahuan dan 
kebudayaan serta pemanfaatan lainya yang dapat memajukan kemajuan bangsa demi kepentingan nasional. Seperti halnya yang ada dalam Undang-undang Dasar Republik Indonesia pasal 32 ayat (1) bahwa : "Negara memajukan kebudayaan nasional Indonesia di tengah peradaban dunia dengan menjamin kebebasan masyarakat dalam memelihara dan mengembangkan nilai-nilai budayanya". Dengan demikian semua masyarakat indonesia dari berbagai lapisan harus bisa menghayati dan mencerminkan nilai-nilai luhur yang ada di Indonesia sebagai pakuan pondasi untuk memperkokoh persatuan dan kesatuan.

Partisipasi masyarakat dalam pelestarian warisan budaya merupakan suatu prioritas yang harus dicapai dalam kegiatan yang memptahankan cagar budaya yang berkaitan dengan pelestarian (Wirastari \& Suprihardjo, 2012). Diharapkan dengan demikian masyarakat bisa sadar akan pentingnya keberadaan benda-benda peninggalan sejarah sehingga nantinya yang berperan penting dalam pelestarian situs cagar budaya tersebut serta pemerintah desa hanya untuk mengayomi dan mengawasi setiap kegiatan sehingga tidak akan keluar dari koridor hukum tentang pelestarian. Selain itu dukungan dari pemerintah setempat seperti kepala desa mempunyai peranan penting untuk keberlangsungan pembangunan suatu desa (Ningrum et al., 2021).

Dalam pelestarian sebuah situs cagar budaya disuatu tempat, perlu adanya peran aktif masyarakat disekitar situs tersebut. Partisipasi masyarakat dalam pelestarian sebuah situs menjadi sebuah hal yang penting untuk perkembangan, penjagaan, dan pelestarian sebuah situs tersebut. Partisipasi masyarakat dalam upaya pelestarian situs cagar budaya merupakan salah satu prioritas yang harus tercapai dalam setiap kegiatan pelestarian benda cagary budaya yang berwawasan pelestarian (Amanda \& Suprihardjo, 2012). Partisipasi masyarakat bisa ditempuh dalam beberapa bentuk, pertama partisipasi ide, partisipasi ide ini adalah bentuk keterlibatan yang mengarah pada perumusan, perencangan, partisipasi ide ini dilakukan ketika melakukan suatau kegiatan di lingkup suatu wilayah tersebut.

Di ujung Desa Karangpatihan yang dikenal dengan desa yang sangat padat penduduk dan mempunyai banyak potensi dibidang pariwisata dan sejarah yang terletak di Kecamatan Balong, Kabupaten Ponorogo disini terdapat sebuah sejarah keberadaan kolam air yang difungsikan pada zaman dahulu sebagai pemandian dan untuk keprluan masyarakat yang bernama Sendang Beji. 
Di sekitarnya kolam tersebut terdapat berbagai pahatan arca yang dulu ada 9 arca namun pada saat ini tinggal hanya 2 yang diperkirakan berusia sudah bertahun-tahun dilihat dari bentuk pahatannya. Arca yang terdapat dalam sendang mbeji kemungkinan dijadikan sebagai simbol kepercayaan pada masyarakat zaman dahulu besar kemungkinan sendang mbeji ini dulu juga digunakan untuk beribadah hal itu bersadarkan adanya arca yang berada disitu dan tempat khusus untuk ritual juga ada disitu. Masyarakat sekitar sangat menyakini kolam berukuran 16x16 meter itu, merupakan peninggalan Kerajaan Majapahit yang terletak di desa karangpatihan.

Pada tahun 2017 lalu, kolam tersebut juga sudah diteliti oleh tim Balai Pelestarian Cagar Budaya (BPCB) dari Trowulan, Mojokerto. Tim tersebut melakukan penelitian di desa Karangpatihan tepatnya di situs Ndoro Den Panji diperkirakan peninggalan kerajaan Mataram Kuno pada abad $10 \mathrm{M}$ atau pada era Empu Sendok di Jawa Timur (Sugianto, 2016). Berdasarkan dari ciri-ciri yang dilihat dari bangunan pahatan arca yang ditemukan di didekat pertirtaan diindentifikasikan sebagai arca Gupala dan Arca Agesti dugaan tersebut dikemukakan berdasarkan dari pada karakteristik Kendi Kumandalu yang berada tepat di pegangan tangan kiri arca tersebut namu tidak dapat dipastikan tahun pembuatan arca tersebut hal ini dikarenakan tidak ada ciri yang menandakan kapan arca tersebut dibuat namun perkiraan mengenai arca tersebut dibuat sudah berusia puluhan tahun yang silam (Ulfah \& Sugianto, 2016).

Pelestarian kawasan cagar budaya dengan adanya partisipasi dari masyarakat lebih efektif dalam menjaga kelestarikan situs cagar budaya tersebut dibandingkan hanya sebuah aturan untuk penjagaan dan perlindungan saja. Oleh karena itu penenlitian ini diharapkan dapat membantu menambah wawasan tentang partisipasi masyarakat terhadap pelestarian situs cagar budaya yang terletak di desa karangpatihan.

Tujuan penulisan artikel ini adalah untuk mengungkapkan hasil penelitian tentang analisis tentang bagaimana bentuk partisipasi masyarakat terhadap pelestarian situs Cagar Budaya Sendang Beji di Desa Karangpatihan Kabupaten Ponorogo.

\section{METODE PENELITIAN}

Metode yang digunakan dalam penelitian ini menggunakan metode deskriptif kualitatif. Penelitian ini dilakukan di Desa Karangpatihan, Kabupaten Ponorogo. Subjek penelitian dalam penelitian ini adalah masyarakat 
desa Karangpatihan khususnya yang tinggal di wilayah sekitar situs Sendang Beji. Teknik pengumpulan data menggunakan teknik wawancara, observasi dan dokumentasi. Analisis data menggunakan Miles dan Huberman yaitu Data Reduction. Data Display, dan Conclusion drawing/verification (Sugiyono, 2020).

\section{HASIL DAN PEMBAHASAN}

\section{Sejarah Cagar Budaya Sendang Mbeji}

Sejarah merupakan semua peristiwa yang terjadi dimasa lalu yang sangat berhubungan dengan cerita bertarikh yang penafsirannya dari kejadian-kejadian yang terjadi di masa lampau yang dceritakan secara terun-temurun dari generasi ke genarasi dengan maksud untuk memberikan gambaran tentang cerita dimasa lalu dan masa yang akan mendatang (Zed, 2018). Hubungan sejarah dengan manusia sangat dekat dimana semua aktivitas yang manusia lakukan yang mencangkup peristiwa atau sebuah tindakan sangat erat kaitannya dengan sejarah. Seperti halnya Bangunan yang bersejarah dikategorikan masuk dalam bangunan cagar budaya peninggalan sejarah sudah semstinya harus kita jaga bersama dan melindungi keberadaanya dalam kaitannya dengan Pelestarian,bangunan sejarah tidak hanya dipandang dari segi keindahan arsitekturnya namun dari nilai historis yang terkandung di dalamnya karena sangat penting bagi ilmu pengetahuan,pendidikan,agama, dan kebudayaan.

Situs Cagar Budaya Sendang Beji yang berlokasi di Kabupaten Ponorogo, Kecamatan Balong, yang terletak tempatnya di desa Karangpatihan sebagai situs peninggalan pada masa peninggalan Mataram Kuno yang keberdaannya harus dipedulikan dan di lestarikan. Situs Cagar Budaya Sendang Beji atau masyarakat menyebutnya dengan Petirtaan Ndoro Den Panji merupakan salah satu situs sejarah yang ada di Kabupaten Ponorogo Kecamatan Balong Dan tepat nya di Desa Karangpatihan disekeliling Sendang Beji banyak ditemukan arca-acra dan juga batu bata yang tersusun di sekeliling Sendang Beji di perkirakan berusia ratusan tahun yang merupakan benda situs bersejarah pada zaman dahulu.

Menurut balai Pelestarian Peninggalan Purbakala(PB3) yang telah melakukan kunjungan di Petirtaan Ndoro Den Panji diperkirakan peninggalan Kerajaan Mataram Kuno pada Abad 10M yang ada di Sendang Beji atau pada masa kekuasaan Empu Sendok di Jawa Timur. Berdasarkan arca-arca yang di temukan disekeliling Sendang Beji yang dapat di identifikasi ada dua arca Gupala dan Arca Agesti dugaan tersebut di perkuat dengan 
karakteristik Kendi Kumandalu yang berada dalaom genggaman tangan kiri arca.

\section{Kondisi Cagar Budaya Sendang Mbeji}

Dari sekian banyak Budaya Nasional yang ada di Indonesia yang sangat perlu di perhatiakan salah satunya berupa bendabenda peninggalan yang mengandung nilai-nilai sejarah Cagar Budaya yang merupakan bagian penting dari bangsa kita didalamnya mempunyai nilai kekayaan budaya yang bermanfaat bagi pemahaman dan pengembangan sejarah, serta ilmu pengetahuan juga termasuk penting dalam kebudayaan sehingga perlu dilestarikan dan dilindungi keberadaannya sebagai jati diri bangsa serta diharapkan bisa berperan dalam kepentingan Nasional.

Seperti yang penulis lakukan dalam penelitian Cagar Budaya Sendang Beji yang berada di Desa Karangpatihan ini. Pemerintah Desa dalam strateginya terus melakukan penggalian potensi salah satunya di tempat adanya Cagar Budaya Sendang Beji yang mempunyai nilai-nilai sejarah yang sangat berhubungan erat dengan masyarakat sekitar yang keberadannya sangat membantu masyarakat sekitar tempat. Pemerintah Desa berupaya melakukan pembangunanpembangunan meski belum bisa menyeluruh dan masih bertahap, hal ini dikarenakan faktor pendanaan yang masih belum bisa mencukupi. Tidak hanya itu pemerintah Desa juga bekerja sama dengan Desa lainnya untuk merekomdasikan wisat-wisata atau tempat sejarah yang ada di Desa Karangpatihan. Hal ini dilakukan supaya bisa membangkitkan minat dari Desa lainnya bawasanya situs sejarah itu sangat penting keberadannya dan kita sebgai penerusnya wajib untukmenjaga dan meestarikannya. Untuk saat ini pemerintah Desa juga terus melakukan upaya pembersihan dan pemeliharaan tempat temapat yang di anggap memiliki sejarah dan berptensi untuk kedannya bisa di kembangkan dalam wisata.

Selain itu pemerintah Desa Karangpatihan juga membentuk Pokdarwis dimana sebagai perentara atau wadah dari kumpulan Kelompok Sadar Wisata untuk mengelola dan mengembangkan tempattempat di Desa Karangpatihan yang mempunyai potensi sejarah dan edukasi diharap dengan keberadaanya Pokdarwis ini bisa membantu masyarakat menyadari dan menjaga serta melakukan tindakan pengawasan terhadap situs-'situs sejarah atau peduli lingkungan yang kedepannya diharapkan bisa membantu dalam menumbuhkan perkonomian masyarakat desa setempat. 


\section{Analisis Partisipasi Masyarakat Terhadap Pelestarian Situs Cagar Budaya Sendang Beji}

Berdasarkan data yang diperoleh selama kegiatan penelitian yang dilakukan di Desa Karangpatihan, maka akan dideskripsikan partisipasi apa saja yang masyarakat lakukan terhadap pelestarian situs cagar budaya sendang beji dilihat dari teori dan jenis-jenis partisipasi.

Bentuk-bentuk partisipasi masyarakat menurut Huraerah (Laksana, 2013) terdiri dari beberapa aspek. Adapun bentukbentuk tersebut antara lain; a) partisipasi buah pikiran; b) partisipasi tenaga; c)partisipasi harta benda; d)partisipasi keterampilan dan kemahiran; e) partisipasi sosial.

Partisipasi berupa buah pikiran atau sumbangan ide dari masyarakat untuk ikut dalam pelestarian situs cagar budaya sendang beji. Ini merupakan tahap awal untuk masyarakat memberikan perencanaan dalam sebuah kegiatan. Pada tahap ini masyarakat desa karangpatihan memberikan sumbangan berupa ide secara langsung melalui perangkat desa RT setempat. Dalam hal ini partisipasi dalam tahap perencanaan masyarakat turut dalam pengambilan keputusan yang terkait dengan situs sendang beji.

Bentuk partisipasi selanjutnya yaitu bentuk partisipasi tenaga. Seperti hasil wawancara yang saya lakukan dengan
Bapak Panut selaku masyarakat setempat beliau salah satu masyarakat yang aktif dalam kegiatan atau perencanaan di tempat situs sejarah sendang beji dari beliau mendapat informasi bawaanya masyarakat yang sadar akan sejarah dan pentingnya cagar budaya banyak yang andil dalam situs sendang beji seperti hal nya bapak panut yang turut memberikan tenaga suka rela untuk membersihkan temapat situs sendang beji tersebut beliau mengatakan kalau kita dalam hal baik dan di lakukan dengan bukti langsung di lapangan masyarakat lain akan melihat dan tersentuh hatinya bisa juga menarik masyaraat yang belum sadar supaya juga turut dalam pemeliharaan situs sendang beji ini.

Perkataan bapak panut tersebut di benarkan dengan pendapat narasumber Amir selaku pemuda setempat sendang beji gerakan dari pemuda tersebut untuk keberadaan Sendang Beji dilakukan secara menyeluruh selama 6 bulan sekalii atau satu tahun sekali dengan diagendakan kerja bakti dalam hal ini melibatkan semua masyarakat serta tokok pemerintah desa. Partisipasi Tenaga dalam hal ini masyarakat desa karangpatihan merealisasikan dengan baik hal ini sesuai dengan observasi di lapangan Kegiatan yang dilakukan antaranya melakukan pembenahan terhadap benda benda di temapat situs budaya melakukan penyemprotan untuk tanaman liar di 
sekililing situs sendang beji dan juga meakukan penanaman pohon yang yang berpotensi mempunyai sumber air dengan demikian di harap air sendang beji bisa selalu terjaga pada musim dengan kemarau tiba sehingga lingkungan sendang beji memiliki suasana yang bersih dan asri.

Selanjutnya bentuk yang ketiga yaitu partisipasi harta benda masyarakat turut dalam kontribuksi pendanaan atau iuran serta sumbangan peralatan untuk kegitan kerja bakti sehingga ini berkaitan dengan teori partisipasi yang telah menyumbangkan uang untuk keperluan kegiatan dan alat-alat yang di anggap bisa berguna untuk kegiatan kerja bakti.

Bentuk yang keempat yaitu partisipasi kemahiran dan keterampilan untuk saat ini partisipasi untuk tahap ini belum terealisasikan di lingkungan masyarakat jenis dapat dilihat jika situs sendang beji sudah resmi dan di buka untuk wisata sehingga dapat menekankan masyarakat untuk mebuat keterampilan yang bisa membantu menyongsong perekonomian masyarakat desa setempat.

Selanjutnya bentuk partisipasi terakhir yaitu partisipasi sosial masyarakat di desa karangpatihan terutama di sendang beji mempunyai komunkasi dengan warganya sangat baik ini dilihat dalam perkumpulan masyarakat dalam tatapan bertemu di jalan masyarakat sangat intens serta menjaga kerukunan dan menjunjung tinggi nilainilai kekeluargaaan.

Dari analisis yang dilakukan di tempat situs sejarah sendang beji partisipasi masyarakat mulai berpengaruh beberapa masyarakat yang terpengaruh terutama seperti masyarakat setempat yang tinggal lama di sekeliling situs sejarah sendang beji yang tau akan sejarah dan ketergantungan masyarakat pada masa terdahulu sehingga mereka bergerak semangat dan tetap menjaga situs sejarah sendang beji dalam kegiatan yang di lakukan di sendang beji. untuk masyarakat pendatang di sekitar sendang beji seperti dikatakan dalam wawancara peneliti oleh Mbak (Supreh) warga pendatang yang baru di sekitar temapat Sendang Beji beliau juga turut berpartisipasi terkait keberadaan sendang beji yang peneliti dapatkan beliau menyumbangkan dana atau konsumsi jika ada kegiatan masyarakat yang dilakukan di sendang beji serta rasa kekeluargaan dan kerukunan yang terjalin dengan turun menurun.

Wirastari dan Supriharjo (Fauzi \& Azis, 2020) merumuskan bawasanya masyarakat dalam pelestarian Cagar Budaya adalah menyangkut keterlibatan masyarakat setemapat atau organisasi bisa juga dengan komunitas yang sadar akan wisata dan situs sejarah dengan suka rela untuk proses pembuatan keputusan, pengelolaan dan menginplementasikannya dalam sebuah 
program. Sehingga dapat tercapainya sebuah tujuan bersama. Pendapat Wirastari, Mikkelsen (dalam Yulianti, 2005:26) menyatakan bawasanya partisipasi adalah wujud dari keterlibatan masyarakat secara suka rela atau bagi yang mau dan peduli untuk perbuahan yang berdampak pada ketentuannya sendiri. Jika melihat pernyataan tersebut masyarakat sangat berperan penting dalam perbuahan bagi kelompoknya. Dari pernyataan tersebut bila dihubungkan dengan pelestarian Cagar Budaya maka Partisipasi masyarakat berdampak penting bersifat pokok dalam keberlansungan Cagar Budaya tersebut bisa terjaga dan di pelihara dengan baik atau juga bisa hancur karena termakan usia.

Situs Cagar Budaya bisa berupa suatu benda benda peninggalan pada zaman dahulu yang keberadannya merupakan sumber kekayaan budaya bangsa yang bermakna penting artinya bagi kepentingan pemahaman dan pengembangan sejarah di Indonesia, untuk menjaga pelestarian benda Cagar Budaya di tentukan langkah dalam peraturan, penguasaan dan pemanfaatan serta pengawasan benda Cagar Budaya.

Benda Cagar Budaya perlu dalam adanya dorongan dari semua kalangan yang sadar akan peninggalan sejarah sehingga perawatan dan pengawasan dapat tercapai dengan baik. Mnueur Adhisakti dalam (Fauzi \& Azis, 2020) prinsip penting dalam pelestarian kebudayaan Indonesia yaitu :

a. Masyarakat sebagai pusat pengelolaan

b. Pentingnya kerjasama antar disiplin ilmu

c. Tercipta mekanisme kelembagaan yang mampu mengakomodasi partisipasi dan aksi masyarakat

d. Dukungan aspek legal dan perlu diwujudkan pasar pelestarian utuk menunjang terciptanya kesinambugan pengelolaan.

Pelestarian Cagar Budaya situs peninggalan sejarah yang ada di desa karangpatihan memang merupakan bendabenda yang harus dipelihara dan harus di lestarikan dengan hasil observasi di lapangan masyarakat mengetahui hal tersebut untuk menjaga dan memelihara keberadannya masyarakat seperti kegiatan yang dilakukan masyaraat sekitar setahun sekali temapatnya pada bulan Suro sebagaian masyarakat setemapat melakukan sedah bumi yang di lakukan di tempat situs cagar budaya sendang beji dengan dilaksakan upacara adat yang di bimbingan langsung oleh juru kunci sendang beji yaitu (Bapak Sugito) Wawancara hal ini di lakukan sebagai wujud syukur dari masyarakat terhadap situs sendang beji yang letaknya dekat permukiman warga dan bertempatan dengan persawahan warga sehingga pada 
musim kemarau air dari sendang beji di gunkan warga untuk perairan persawahan.

Pelestarian untuk mempertahankan keberadaan situs cagar budaya sendang beji sebagai upaya yang dinamis dengan cara perlindungan,pengembangan, dan pemanfaatan( Undang-'undang Replublik Indonesia Nomor,11 Pasal 1 Ayat 22 Tahun $2010 \quad$ Tentang Cagar Budaya,2010:5) Salah satunya menetapkan situs cagar budaya sendang beji sebagai situs sejarah tertua sebelum makam Batarakatong yang ada di Ponorogo yang disampaikan oleh Juru kunci saat wawancara di lapangan.

Bentuk pelestarian adalah dengan di berlakukannya perlindungan terhadap benda-benda peninggalan sejarah menurut Prasetyo dan Warsito (2014:84) upaya dari perlindungan dari bahaya kemusnahan agar tetap terawat dan terjaga keberadannya.

Penyelamatan situs juga dilakukan oleh masyarakat sekitar sendang beji jika ditemukan penemuan baru pemerintah desa mengarapakan masyrakat melaporkan pada pengelola utama situs yaitu juru kunci sendang beji kemudian di teruskan ke pada pihak yang berwenang dengan demikian bisa di tindak lanjutan kepada pihak BPCB. Jika terbukti barang penemuan masyarakat terbukti sebagai benda, bangunan atau struktur Cagar Budaya. Selain itu juga dilakukannya
Zonasi yang merupakan upaya perlindungan dan pembatasan wilayahwilayah yang diluar batas dari sendang beji sesuai observasi di lapangan yang peneliti lihat letak sendang beji perbatasan dengan persawahan warga sehinga aktivitas yang sering datang ke lokasi sendang beji adalah masyarakat yang mengelola persawahan di dekatnya situs.

Pemeliharaan dilakukan dengan berbagai upaya menetapakan satu juru pelihara yaitu masyarakat desa karangpatihan dan bekerjaa sama dengan pemuda setempat hal ini di lakukan supaya mempermudahkan terhadapap pemeliharaan situs sejarah Sendang Beji sehingga di kawasan tempat sendang beji dapat terjaga terutama bagian tempat kolam Sendang Beji yang harus sering dilakukan pembersihan rutin selama satu bulan sekali atau satu minggu sekali supaya terciptanya lingkungan sendang beji yang bersih dan air yang jernih.Kegiatan untuk menjalin gotong royong dan menciptakan kerukunan serta kekompakan masyarakat dalam pemeliharaan situs sendang beji terlihat kegiatan yang di agendakan masyarakat setempat. Pemugaran di sendang beji masih dilakukan bertahap hal ini di karenakan kurangnya sumber daya manusia dan juga keterbatasan dalam pendanaan. 


\section{KESIMPULAN}

Berdasarkan penelitian yang telah dilakukan mendapatkan hasil mengenai analisis paartisipasi masyarakat terhadap pelestarian situs Cagar Budaya Sendang Beji Desa Karangpatihan, Kabupaten Ponorogo maka dapat di simpulkan :

Partisipasi Buah Pikiran partisipasi berupa buah pikiran atau sumbangan ide dari masyarakat untuk ikut dalam pelestarian situs cagar budaya sendang beji. Ini merupakan tahap awal untuk masyarakat memberikan perencanaan dalam sebuah kegiatan. Partisipasi Tenaga dalam hal ini masyarakat desa karangpatihan merealisasikan dengan baik hal ini sesuai dengan observasi di lapangan, kegiatan yang dilakukan antaranya melakukan pembenahan terhadap benda benda di temapat situs budaya melakukan penyemprotan untuk tanaman liar di sekililing situs sendang beji dan juga meakukan penanaman pohon yang yang berpotensi mempunyai sumber air dengan demikian di harap air sendang beji bisa selalu terjaga pada musim dengan kemarau tiba sehingga lingkungan sendang beji memiliki suasana yang bersih dan asri. Partisipasi Harta Benda masyarakat turut dalam kontribuksi pendanaan untuk kegiatan atau pengelolaan situs cagar budaya sendang beji.

Partisipasi Kemahiran dan Keterampilan untuk kondisi saat ini di lihat dari partisipasi masyarakat pada tahap ini belum terealisasikan di lingkungan masyarakat sendang beji. Dilihat dari Partisipasi Sosial masyarakat di desa karangpatihan terutama di sendang beji mempunyai komunkasi dengan warganya sangat baik dengan kerja sama anatar warganya terjalin harmonis ini dilihat dalam perkumpulan masyarakat melkukan kegiatan gotong royong dalam perbaikan di situs sendang beji.

Pelestarian untuk mempertahankan keberadaan situs cagar budaya sendang beji sebagai upaya yang dinamis dengan cara perlindungan,pengembangan, dan pemanfaatan. Bentuk pelestarian adalah dengan di berlakukannya perlindungan terhadap benda-benda peninggalan sejarah - perlindungan termasuk penylamatan dan pengamanan,zonasi serta pemeliharaan dan pemugaran. zonasi yang merupakan upaya perlindungan dan pembatasan wilayah-wilayah yang diluar batas dari sendang beji Pemeliharaan dilakukan dengan berbagai upaya menetapakan satu juru pelihara yaitu masyarakat desa karangpatihan dan bekerjaa sama dengan pemuda setempat hal ini di lakukan supaya mempermudahkan terhadapap pemeliharaan.

\section{DAFTAR PUSTAKA}

Abdillah, J. (2020). Analisis Peran

Partisipasi Masyarakat Dan 
Pemerintah Desa Dalam Upaya Pengelolaan Dan Pelestarian Cagar Budaya Di Desa Kota Kapur Kecamatan Mendo Barat Kabupaten Bangka. Jurnal Hukum Doctrinal, 5(2), 187-191.

Amanda, V., \& Suprihardjo, R. (2012). Pelestarian_Kawasan_Cagar_Buday a_Berbasis_Partisip. 1(1).

Arinto, F. X. E. (2018). Pelestarian arsitektur berdasarkan architectural architypes melalui metode grafis. ARTEKS: Jurnal Teknik Arsitektur, 3(1), 29-36.

Cahyono, H., UTAMI, P. S., \& Asmaroini, A. P. (2020). Pengembangan Model Pembelajaran Multikultural Terintegrasi Mata Kuliah Kewarganegaraan Di Perguruan Tinggi. JPK: Jurnal Pancasila Dan Kewarganegaraan, 5(1).

Fauzi, R., \& Azis, A. (2020). Partisipasi Masyarakat Dalam Pelestarian Situs Batu Bedil Di Kecamatan Bayah. Jurnal Kala Manca, 8(1), 10-18.

Laksana, N. S. (2013). Bentuk-bentuk partisipasi masyarakat desa dalam program desa siaga di Desa Bandung, Kecamatan Playen, Kabupaten Gunung Kidul, Provinsi Daerah Istimewa Yogyakarta. Jurnal Kebijakan Dan Manajemen Publik, 1(1Hal), 56-57.

Ningrum, L., Mahardhani, A. J., \& Utami, P. S. (2021). Peran Kepala Desa Terhadap Pembangunan Di Desa Wates Kecamatan Jenangan Kabupaten Ponorogo.

Sugianto, A. (2016). Kajian Potensi Desa Wisata Sebagai Peningkatan Ekonomi Masyarakat Desa Karang Patihan Kecamatan Balong 1 Ponorogo. Ekuilibrium: Jurnal Ilmiah Bidang
Ilmu Ekonomi, 11(1), 56-64.

Sugiyono. (2020). Metode Penelitian

Kuantitatif, Kualitatif, dan R\&D

(Sutopo (ed.); 2nd ed.). Alfabeta.

Sularsih, S. (2012). Harmonisasi Undangundang Nomor 11 Tahun 2010

Tentang Cagar Budaya dan Undangundang Nomor 19 Tahun 2002 Tentang Hak Cipta dalam Pelindungan Arsitektural Bangunan Cagar Budaya. Jurnal Konservasi Cagar Budaya, 6(1), 50-59.

Sulton, Yulia Wulansari, B., \& Sinta Utami, P. (2020). Wayang Golek Reog Ponorogo: The Acculturation of Indonesian Culture As Patriotism Character Education Learning Medium to Early Age Children. $K n E$ Social Sciences, 2020, 299-305. https://doi.org/10.18502/kss.v4i4.649 4

Ulfah, I. F., \& Sugianto, A. (2016). Revolusi Mental Kampung Idiot Menuju Desa Wisata Berbasis Kearifan Lokal Sebuah Strategi Peningkatan Ekonomi Masyarakat Desa Karangpatihan Balong Ponorogo Prosiding Seminar Nasional Hasil-Hasil Penelitian 2016:Bidang Agama Islam,Budaya,Ekonomi,Sosial Humaniora, Teknologi,Kesehatam, dan Pendidikan, 213-224.

Wirastari, V. A., \& Suprihardjo, R. (2012). Pelestarian Kawasan Cagar Budaya Berbasis Partisipasi Masyarakat (Studi Kasus: Kawasan Cagar Budaya Bubutan, Surabaya). Jurnal Teknik ITS, 1(1), C63-C67.

Wulansari, B. Y., \& Utami, P. S. (2019). Characters Of Wayang Golek Reog Ponorogo In Patriotism Education Learning To Early Childhood. JURNAL INDRIA (Jurnal Ilmiah 
Pendidikan Prasekolah Dan Sekolah Awal), 4(2).

Zed, M. (2018). Tentang konsep berfikir sejarah. Lensa Budaya: Jurnal Ilmiah Ilmu-Ilmu Budaya, 13(1). 